\title{
Estudo do Índice Crioscópico do leite Tipo B in natura produzido na bacia leiteira do Vale do Taquari,RS*
}

\author{
CLEUSA SCAPINI BECCHI \\ Guiomar Pedro Bergmann (Orientador - UFRGS)
}

Banca: José Maria Wiest (UFRGS), Isa Beatriz Noll (UFRGS), Luciana Ruschel dos Santos (UPF)

\begin{abstract}
O índice crioscópico é um dos parâmetros analíticos de precisão utilizados para determinar a qualidade físicoquímica do leite. É um valor diretamente ligado ao extrato seco do leite, mais especificamente em relação a presença, maior ou menor, de lactose e cloretos. A adição de água ao leite, como mecanismo de fraude, altera os valores do índice crioscópico. Em virtude disto, o mesmo é utilizado como um dos critérios para desclassificação de leite. O problema se estabelece quando os padrões determinados em legislação não condizem com as características reais do leite produzido. O presente trabalho objetivou comparar os resultados do índice crioscópico do leite tipo B "in natura" da bacia leiteira do Vale do Taquari com o valor estabelecido na legislação vigente, bem como observou as alterações deste parâmetro ao longo de um ano. O projeto foi desenvolvido no período de março de 2001 a fevereiro de 2002, com a participação de 10 propriedades produtoras de leite tipo B, onde as coletas foram realizadas mensalmente, perfazendo um total de 573 amostras no período. Os resultados analíticos foram obtidos mediante as análises de acidez, temperatura, densidade, gordura, extrato seco total (EST), extrato seco desengordurado (ESD) e índice crioscópico (IC). Quanto ao comportamento do índice crioscópico, o diagnóstico confirmou a necessidade imprescindível da implementação de parâmetros legais regionais, respeitando as características específicas de cada região. A pesquisa apresentou para o leite tipo B "in natura" do Vale do Taquari, um índice crioscópico médio de $-0,537^{\circ} \mathrm{H}$, enquadrando-se no parâmetro estabelecido pela Instrução Normativa $\mathrm{N}^{\circ} 51$ de 18/09/02, ou seja, máximo de $-0,530{ }^{\circ} \mathrm{H}$. Este índice também apresentou valor médio mais baixo nos meses de junho e julho e as variações mensais individuais foram significativas. Estes comportamentos indicam que a alimentação ofertada ao rebanho influencia nestas alterações.
\end{abstract}

Descritores: leite, índice crioscópico, alimentação, parâmetros legais, Vale do Taquari.

Apresentada: 27 junho 2003

*Dissertação de Mestrado n. 353 (Especialidade: Inspeção e Tecnologia de Produtos de Origem Animal). 106f. Programa de Pós-graduação em Ciências Veterinárias da Faculdade de Veterinária - UFRGS, Porto Alegre/RS. CORRESPONDÊNCIA: C.S. Becchi [cbecchi@fates.tche.br]. 


\title{
Study of cryoscopic rate of Type B milk in natura produced in dairy farms in the Taquari Valley, RS**
}

\author{
CLEUSA SCAPINI BECCHI \\ Guiomar Pedro Bergmann (Adviser - UFRGS) \\ Committee: José Maria Wiest (UFRGS), Isa Beatriz Noll (UFRGS), Luciana Ruschel dos Santos (UPF)
}

The cryoscopic rate is one of the analytic parameters of accuracy used to determine the physical-chemical_quality of milk. This rate is directly related to the dry extract of milk, more specifically related to its higher or lower content of lactose and chloride. Adding water to milk, as a fraude mechanism, changes the cryoscopic rates. The cryoscopic rate is, therefore, used as a criterion to disqualify milk. The problem is posed when the law standards in force are not suitable to the actual characteristics of the milk produced. This study aimed at comparing the results of cryoscopic rate of type B milk "in natura" produced in dairy farms in the Taquari Valley with the relevant law standards in force, as well as observing changes in cryoscopic rate over a year lapse. The project was developed from March 2001 to February 2002, encompassing ten dairy farms wich produce B milk. Samples were collected monthly totalizing 573 samples during that time lapse. The analytic results were obtained by the analysis of acidity, temperature, density, fat, total dry extract (EST), defat dry extract (ESD) and cryoscopic rate (IC). As for the cryoscopic rate behavior, the diagnosis confirmed the vital necessity of establishing regional legal standards, according to the particular characteristics of each region. The research showed an average cryoscopic rate of $-0,537{ }^{\circ} \mathrm{H}$ for B milk "in natura" in the Taquari Valley. This rate accomodates with the parameters established by Normative Ruling number 51 of 09/18/02. This rate also showed lower average value in the months of June and July, and the individual monthly fluctuations were significant. These behaviors indicate that feeding influences the fluctuations.

Key words: milk, cryoscopic rate, feeding, legal standards, Taquari Valley.

\footnotetext{
**Master's Thesis \# 353 (Field: Food and Meat Inspection) 106p. Graduate Program in Veterinary Sciences, Universidade Federal do Rio Grande do Sul (UFRGS), Porto Alegre/Brazil. CORRESPONDENCE: C.S. Becchi [cbecchi@fates.tche.br].
} 